\section{Irrigation and Rootstock Influence on Water Use, Tree Growth, Yield, and Fruit Quality at Harvest at Different Ages of Trees in 'Pacific Gala' Apple}

\author{
Esmaeil Fallahi ${ }^{1,4}$, Bahar Fallahi ${ }^{2}$, and Bahman Shafii ${ }^{3}$ \\ University of Idaho, College of Agricultural and Life Sciences, Parma \\ Research and Extension Center, 29603 U of I Lane, Parma, ID 83660
}

Additional index words. evapotranspiration, irrigation scheduling, Malus domestica

\begin{abstract}
During various ages of tree between 2002 and 2007, the effects of four rootstocks and two irrigation systems using a crop evapotranspiration-based (ETc) water scheduling on water use, tree growth, yield, and fruit quality at harvest in 'Pacific Gala' apple [(Malus $\times$ domestica) Borkh] were studied. The use of ETc when a precise crop coefficient value (Kc), modified by percentage of ground shade (GS) and tree canopy maturity (M) was used, provided a reliable tool for irrigation scheduling of 'Pacific Gala' apple. Young trees with a full sprinkler (FS) system received an average of $872.3 \mathrm{~mm}(5616.8 \mathrm{~L} / \mathrm{tree})$, whereas those with full drip (FD) received $448.9 \mathrm{~mm}(2921.1 \mathrm{~L} /$ tree). However, when trees were mature, trees with a FS system received an average of $994 \mathrm{~mm}(6461.7 \mathrm{~L} /$ tree $)$, whereas trees with a FD received $614.1 \mathrm{~mm}(3996 \mathrm{~L} /$ tree $)$ of irrigation water per growing season. Trees on 'Budagovsky 9' ('B.9') had smaller trunk cross-sectional area (TCA) and higher yield efficiency, whereas those on 'Supporter4' ('Sup.4') had larger TCA and lower yield efficiency than those on other rootstocks in all years of the study. Trees on 'Nic.9' ('RN29') always had higher yield per tree as compared with those on other rootstocks. Trees on 'RN29' often had higher but trees on 'B.9' had lower fruit weight than did those on other rootstocks. Trees on 'Sup.4', despite their lower yields, had smaller fruits than those on 'RN29' every year and thus were not suitable for planting. Fruit from trees on 'B.9' and 'Cornell-Geneva30' ('G.30') often had higher soluble solids concentration (SSC) and starch degradation pattern (SDP) than those other rootstocks. Fruits from trees on 'G.30' also had lower firmness and higher stem-end cracking, suggesting that this rootstock advances maturity in 'Pacific Gala' apple. Trees with FS irrigation had higher TCA than those with the FD system. Trees with the FD system were more precocious and had higher yield per tree, yield efficiency, and fruit weight than trees with the FS system when they were young. However, these differences were not significant when trees matured. 'Pacific Gala' fruit from trees with FS consistently had better color than those with the FD system every year. Fruits from young trees with the FD system often had higher SDP and lower firmness than those from FS irrigation.
\end{abstract}

The increasing trend in the world population and decreasing trend in the available agricultural land and water mandate a more efficient use of water and orchard land. Using new orchard designs with more efficient

Received for publication 31 Dec. 2012. Accepted for publication 20 Feb. 2013.

We thank the Idaho Apple Commission, International Fruit Tree Association, Washington Tree Fruit Research Commission, and the Idaho Agricultural Experiment Station for their financial support of this project. We are also thankful to the Columbia Basin, Van Well, and C \& O Nurseries in Washington State for providing the experimental trees and to Mr. Richard L. Bronson, Pipeco, Fruitland, Idaho, for his invaluable contribution and assistance in designing the irrigation layout and providing the irrigation materials for this project.

${ }^{1}$ Professor and Director of Pomology.

${ }^{2}$ Scientific Aide in Pomology.

${ }^{3}$ Professor and Director of Statistical Program.

${ }^{4}$ To whom reprint requests should be addressed; e-mail efallahi@uidaho.edu. logarithmically earlier in RDI apples. At harvest, RDI fruit were smaller and had a higher SSC and lower titratable acidity (TA). Starch degradation was delayed in RDI fruit, and their color was unaffected. Firmness was unaffected when the effect of size on firmness was removed. The SSC of RDI apples remained higher during storage, but starch content, TA, firmness, and color were similar.

Leib et al. (2006) indicated that fruit size and yield of 'Fuji' apple in deficit irrigation (DI) were similar to those of partial root zone drying irrigation and conventional irrigation (CI) in the semiarid climate of Washington State. Naor et al. (2008) reported that yield and fruit size decreased as the rate of irrigation was reduced in 'Golden Delicious' apple in Israel. Previous reports have indicated that a reduction in water application may result in a reduction in apple firmness, relating this observation to the advanced maturity in fruit with water stress (Drake et al., 1981; Mills et al., 1994). However, other studies have shown that apples from non-irrigated plots were firmer than those from irrigated plots because fruit from non-treated plots had smaller size (Assaf et al., 1975).

Irrigation with a drip system uses lower water volume than sprinkler irrigation (Fallahi et al., 2007a; Proebsting, 1994). However, irrigation through microjet sprinkler systems can improve the establishment and maintenance of orchard floor vegetation. Microjet sprinklers also create a cooler environment in the orchards under the fruit-growing conditions of Washington and Idaho (E. Fallahi, personal observation).

Although there has been some progress in the understanding of microirrigation systems (Chun et al., 2001; Fallahi et al., 2007a; Neilsen et al., 1994, 2010; Yao et al., 2001; Zydlik and Pacholak, 2001), information on tree growth, yield, and fruit quality for new apple cultivars and rootstocks under various regimes of drip or microjet sprinkler irrigation systems in the Pacific Northwestern United States is lacking. Thus, the objective of this long-term experiment was to study the effect of four rootstocks and two irrigation treatments consisting of microjet sprinkler and drip systems using $\mathrm{ET}_{\mathbf{c}}$-based water scheduling on water use, tree growth, yield, and harvest-time fruit quality attributes in 'Pacific Gala' apple at different ages of tree (different years of tree canopy maturity) during 2004-07.

\section{Materials and Methods}

vigor and the most dwarfing rootstocks resulted in the earliest ripening. Rootstock can also influence scion leaf and fruit mineral concentrations and, thus, indirectly affect fruit quality and yield (Fallahi et al., 2001a, 2001b).

Ebel et al. (1993) in a comprehensive study in Washington State applied regulated deficit irrigation (RDI) to 'Delicious' apple trees early in the growing season to determine if fruit quality and storage life would be altered compared with well-watered trees. Internal ethylene concentration increased

\section{Orchard establishment}

The experimental orchard was established at the University of Idaho Parma Research and Extension Center in spring and early summer of 2002. 'Pacific Gala' trees on four rootstocks were planted at $1.52 \times 4.27-\mathrm{m}$ spacing with an east-west row orientation. The rootstocks were: 'Budagovsky 9' ('B.9'), 'Nic9' ('RN29'), 'Cornell-Geneva30' ('G.30'), and 'Supporter4' ('Sup.4'). 'Manchurian' crab apple [(Malus baccata) mandshurica] 
on 'RN29' rootstock (C \& O Nursery, Wenatchee, WA) was planted in each row as a pollenizer between every 10 'Pacific Gala' trees. Trees were trained into a vertical axis central leader system during the dormant season in early March every year. Tree leaders were maintained at a height of $\approx 3.7 \mathrm{~m}$.

The experimental site had a semiarid climate with an annual precipitation of $\approx 297 \mathrm{~mm}$ and a sandy loam soil of $\mathrm{pH} \approx 7.3$. Crested wheatgrass [Agropyron cristatum (L.) Gaertn.], which is a drought-tolerant grass, was planted as the orchard floor cover in all treatments. Weeds were controlled chemically to maintain a $1.22-\mathrm{m}$ weed-free herbicide strip under trees.

Trees in all treatments were blossomthinned at $\approx 80 \%$ bloom with $5 \%$ lime sulfur followed by one or two applications of postbloom thinners. The first post-bloom thinner was a mixture of carbaryl ( $44.1 \%$ by weight a.i.; Sevin XLR; 1-naphthyl N-methylcarbamate; Bayer Crop Science, Research Triangle Park, NC) and ethephon [21.7\% a.i.; Ethrel (2chloroethyl) phosphonic acid; Bayer Crop Science] at a rate of $0.125 \%$ to $0.156 \%$ of formulation and was applied at petal fall. The second post-bloom thinner (when applied, depending on the cropload) was carbaryl (Sevin XLR) at $0.125 \%$ formulation that was applied when fruitlet diameter was $\approx 7 \mathrm{~mm}$. Fruit were subsequently hand-thinned when fruits were $\approx 18 \mathrm{~mm}$ in diameter (around mid-June) to maintain a space of at least 12.5 to $15 \mathrm{~cm}$ between fruits. Kaolin (95\% a.i.; Surround; Englehard, Iselin, NJ) was sprayed for sunburn protection at the rate of $56.8 \mathrm{~kg} \cdot \mathrm{ha}^{-1}$ in early July followed by three 1-week interval applications, each at $28.4 \mathrm{~kg} \cdot \mathrm{ha}^{-1}$ every year.

Cultural practices other than irrigation were similar to those recommended for commercial orchards in the Pacific Northwest (Washington State University, 2012).

\section{Irrigation regimes}

Two irrigation regimes were installed, FS and FD. Each irrigation regime was applied in one row, consisting of four rootstocks as described earlier. A row of guard trees was used between every two experimental rows. These trees received only drip irrigation to prevent any possible overspray from the sprinkler system in the experimental rows. Trees from the guard rows were not used for any part of the study. The two irrigation regimes (FS and FD) in this study were as follows.

Full sprinklers. Thirty-centimeter microjet sprinklers (Olson Ultra-jet, Santee, CA) were connected to a lateral polyethylene line installed in a 14-cm deep trench (subsurface), $30 \mathrm{~cm}$ away from and parallel to the tree row. Each microjet sprinkler was installed midway between two adjacent trees and covered a complete circle with a radius of $2.1 \mathrm{~m}$. In this treatment, trees were irrigated once a week at the full rate of ETc for apple starting in 2002.

Full drip. One 16-mm drip line (Rain Bird Corporation, Azusa, CA) was installed in a 10-cm deep trench (subsurface), $30 \mathrm{~cm}$ away from and parallel to the tree row on each of the north and south sides of the tree row. Each of these lines was connected to a pressure regulator to keep the water pressure constant at $1.41 \mathrm{~kg} \cdot \mathrm{cm}^{-2}$. Pressurecompensating emitters were spaced at $45 \mathrm{~cm}$ on each line, and each emitter delivered $2.27 \mathrm{~L} \cdot \mathrm{h}^{-1}$ of water. Pressure compensation ensured consistent flow from each inline emitter throughout the entire length of tubing and the emitter design prevented debris from clogging emitters for maximum performance. The drip line on the north side of the tree was "offcentered" with the line in the south side to provide better water coverage. Trees in the FD system were irrigated twice a week at $100 \%$ of daily ETc (as described below) but adjusted for the GS. Therefore, in this treatment, liters of water applied per tree $=(E T c$ in $\mathrm{mm} /$ percent drip efficiency factor) $\times$ $1.52 \times 4.27-\mathrm{m}$ spacing $\times \%$ GS.

Irrigation treatments were initiated in approximately mid-May and ended in midOctober every year. Shortly before the first irrigation of the year, soil moisture was measured using AquaPro sensors (AquaPro Sensors, Decor, CA), and trees were watered to the soil saturation point. After this general irrigation, water requirements were calculated based on ETc where ETc $=\mathrm{ETr} \times \mathrm{Kc}$ with ETr (Penman-Monteith reference evapotranspiration) (Allen et al., 1998) being calculated from the Agri-Met Parma Weather Station data and Kc being the crop coefficient. Each year starting 2002, the crop water use coefficient was calculated as: $\mathrm{Kc}=\mathrm{K}_{\mathrm{c}}$ base $+\% \mathrm{M} \times$ (mature $\mathrm{K}_{\mathrm{c}}-\mathrm{K}_{\mathrm{c}}$ base) . Percent canopy $\mathrm{M}$ was a measurement of tree canopy size and was calculated as: $\% \mathrm{M}=$ $3.05+2.558 \times(\% \mathrm{GS})-0.016 \times(\% \mathrm{GS})^{2}$. Kc base was the base coefficient, calculated as the percentage area between the rows that was occupied by a cover crop. In this experiment, spacing between rows was $4.27 \mathrm{~m}$ and the herbicide strip extended $0.61 \mathrm{~m}$ on either side of the row. Thus, Kc base was [4.27 $(0.61 \times 2)] / 4.27=0.71]$. Percentage of GS was estimated as the area of orchard shaded by the tree canopy at different stages of growth. Ground shading reached $62 \%$ and tree maturity reached $100 \%$ in early Aug. 2005 . Thus, Kc values for mature trees were used after 1 Aug. 2005. Because crested wheatgrass was planted as the orchard floor cover plant and some degree of vegetation was maintained for both irrigation systems during the entire growing season and grass was mowed frequently every year, value for mature Kc for each month was adopted from Proebsting (1994) for apple with cover crop, i.e., 0.71 in May, 0.96 in June, 1.04 in July and August, 1.0 in September, and 0.79 in October.

Several random checks were made to test the accuracy of water delivery in both irrigation systems every year. Based on the precision in designing the irrigation systems and these random checks, an efficiency factor of $100 \%$ was assumed for all irrigation treatments. Rainfall during the growing seasons was generally low and when it rained, this amount was subtracted from the ETc value to calculate the actual amount of irrigation needed in each application.

Tree growth, yield, and quality attributes. For monitoring tree growth, TCA was calculated by measuring trunk diameter at $\approx 20 \mathrm{~cm}$ above the bud union $(\approx 12 \mathrm{~cm}$ above the soil line) in early March every year. For this purpose, two measurements were made, one from the east-west and the other one from the north-south directions, and the diameter values were averaged and the radius was computed. Tree TCA $\left(\mathrm{cm}^{2}\right)$ was calculated every year from 2004 through 2007. Yield per tree was recorded at harvest time and yield efficiency was calculated as: (total yield per tree in $\mathrm{kg}$ )/TCA in $\mathrm{cm}^{2}$.

Twenty fruits were randomly sampled from each tree between 10 and 25 Aug. 2004-07. For quality evaluation at harvest, fruits were gently wiped with a damp cloth and percentage of fruit with visible russet was recorded. Fruits were weighed and skin color was visually ranked on a scale of 1 to 5 , with $1=20 \%$ red, progressively to $5=100 \%$ red SSC was measured using a temperaturecompensated refractometer (Atago N1, Tokyo, Japan) and fruit firmness was measured, using an 11-mm probe, with a Fruit Texture Analyzer (Guss, Strand, Western Cape, South Africa). Fruit were visually inspected and percentage of fruits with "stem-end cracking" was recorded. Fruit were then cut equatorially in halves and SDP of equatorial halves of each fruit was recorded by comparison with the SDP standard chart developed for 'Gala' apples by Bartram et al. (1993).

Experimental designs and statistics. The experimental design was a randomized complete block split plot with two irrigation treatments as main plots and four rootstocks as sub-plots and five blocks (replicates). Each block contained 10 trees in each plot of irrigation-rootstock combination, five of which in the center of the plot were used for measurements (i.e., a total of 50 trees per treatment, of which 25 were used for measurements). Data were collected during 2004 through 2007. Computing univariate analyses for all tree responses in this study checked the assumption of normal data distribution. Analyses of variance were conducted by using SAS (SAS Institute, Cary, NC) with PROC GLM and means compared by a least significant difference at $P \leq 0.05$.

\section{Results and Discussion}

\section{Interaction}

There was no significant interaction between year and irrigation or rootstock treatments for any of the amount of applied water, tree growth, yield, or fruit quality attributes (fruit size, color, firmness, SDP, SSC, stemend cracking) in this study. Thus, in addition to the results in each year, results of overall years from 2004 through 2007 are reported for each of these attributes.

\section{Water application}

The average precipitation during the irrigation periods of 2004-05, when trees were 
not yet fully mature, was $66.0 \mathrm{~mm}$, and the average for 2006-07 irrigation periods, when trees were mature, was $55.1 \mathrm{~mm}$ (Table 1). Water application in all irrigation regimes increased as trees matured (Table 1). As expected, trees used the most water in July and August in all years. Trees with FS treatment received a considerably greater volume of water than those with FD every year. Trees with a FS system received $72 \%$ and $56 \%$ more water than those with a FD system in 2003 (data not shown) and 2004 (Table 1), respectively. The differences between water applications in FS and FD 2005 (Table 2) because trees had reached the maximum ground shading $(\approx 62 \%)$ and full canopy maturity after 1 Aug. 2005. On average, young trees with a FS system received an average of $872.3 \mathrm{~mm}(5616.8 \mathrm{~L} /$ tree), whereas those with FD received $448.9 \mathrm{~mm}$ (2921.1 L/tree). However, when trees were mature, trees with a FS system received an average of $994 \mathrm{~mm}(6461.7 \mathrm{~L} /$ tree $)$, whereas trees with a FD received $614.1 \mathrm{~mm}(3996 \mathrm{~L} /$ tree) of irrigation water per growing season (Table 1).

Leib et al. (2006) compared three microsprinkler irrigation systems in mature 'Fuji' trees in Washington State. In that study, the soil water content in the CI was maintained close to field capacity, which was only $60 \%$ to $70 \%$ of estimated ETc for apple without cover crop. They estimated that irrigation scheduling based on soil-water measurements required $26 \%$ less water than what orchard without a cover crop. They found that the 3-year average potential evapotranspiration was $991 \mathrm{~mm}$, ETc was $\approx 790 \mathrm{~mm}$, and irrigation amounts applied were $707 \mathrm{~mm}$ for CI irrigation regimes. In our study when trees were mature (2006 and 2007), the 2-year systems were consistent ( $38 \%$ to $41 \%$ ) after was predicted by the ETc model for an apple

average for ETr was $1106.7 \mathrm{~mm}$ and for ETc was $1050.3 \mathrm{~mm}$ (Table 2), and thus, these values were $\approx 11 \%$ and $25 \%$ higher than similar measurements in Washington, respectively. During 2006 and 2007, we applied an average of $994 \mathrm{~mm}$ of water to the FS trees, which was $\approx 287 \mathrm{~mm}(\approx 29 \%)$ higher than the levels applied to the CI treatment in Washington State (Leib et al., 2006). This difference is perhaps largely the result of the higher ETr and ETc values in Idaho than Washington. We used Kc for orchards with a cover crop, whereas they used Kc for orchards without a cover crop in Washington. The difference could also be in part because trees receiving FS were applied with water at full ETc level in our study (Table 1), whereas CI trees in the Washington experiment received water at $\approx 70 \%$ of ETc. Rainfall in both experiments was somewhat comparable.

\section{Effects of rootstock on tree growth and yield}

'Pacific Gala' trees on 'B.9' had significantly smaller TCA, whereas those on 'Sup.4' had larger TCA than those on other rootstocks all years of the study (Table 2). Trees on 'RN29' were smaller than those on 'G.30' when trees were young in 2004 and 2005 , but the tree size differences between these two rootstocks became insignificant when trees were mature in 2006 and 2007. Based on the foliage density after tree canopy reached $100 \%$ maturity $(\approx 62 \%$ GS as described before), it appeared that $1.52-\mathrm{m}$ spacing between trees was too wide for trees on 'B.9' and could have been reduced to 0.9to $1.2-\mathrm{m}$ spacing for this rootstock. Even between-row spacing for this rootstock could have been reduced from 4.2 to $3.6 \mathrm{~m}$ or $3.9 \mathrm{~m}$ and thus tree density on 'B.9' could have been increased from its current density of 1536 trees/ha to 2069 to 2989 trees/ha.

Table 1. Precipitation, evapotranspiration, depth of applied water, and total volume of applied water per tree in 'Pacific Gala' apple from 2004 to 2007.'

\begin{tabular}{|c|c|c|c|c|c|c|}
\hline & & & Avg & & & Avg \\
\hline $\mathrm{Yr}$ & 2004 & 2005 & $\overline{2004-05}$ & 2006 & 2007 & $\overline{2006-07}$ \\
\hline Precipitation (mm) & 64.9 & 67.2 & 66.0 & 54.4 & 55.9 & 55.1 \\
\hline $\mathrm{ETr}(\mathrm{mm})$ & 925.7 & 956.2 & 941.0 & 1067.9 & 1145.4 & 1106.7 \\
\hline $\operatorname{ETc}(\mathrm{mm})$ & 846.3 & 930.7 & 888.7 & 1022.8 & 1077.7 & 1050.3 \\
\hline Water applied by sprinkler (mm) & 846.3 & 898.2 & 872.3 & 961.2 & 1026.7 & 994.0 \\
\hline Water applied by drip (mm) & 369.4 & 528.4 & 448.9 & 594.5 & 633.6 & 614.1 \\
\hline Applied by sprinkler (L/tree) & 5399.8 & 5833.8 & 5616.8 & 6249.9 & 6673.5 & 6461.7 \\
\hline Applied by drip (L/tree) & 2404.2 & 3438.0 & 2921.1 & 3872.0 & 4121.2 & 3996.0 \\
\hline
\end{tabular}

${ }^{\mathrm{z}} \mathrm{ETr}=$ Penman-Monteith evapotranspiration; ETc = evapotranspiration for crop (apple).
However, $1.52-\mathrm{m}$ spacing was appropriate for trees on 'RN29' rootstock. 'Pacific Gala' trees on 'Sup.4' were too large for planting with the tree spacing of this study.

Trees on 'RN29' had consistently higher yield per tree every year, leading to a higher cumulative yield over the 2004-07 seasons (Table 2). Trees on 'B.9' and 'RN29' were more precocious and had higher yield per tree and yield efficiency than those on 'Sup.4' in 2004 through 2006 ( 2 to 4 years after planting) (Table 2). Thus, both of these rootstocks can be recommended for their yield under closed-space conditions of this study. 'Sup.4' was not a suitable rootstock for 'Pacific Gala' in this study because trees were too large with low yield efficiency.

\section{Effects of rootstock on fruit quality attributes}

Fruit from trees on 'RN29' had greater but trees on 'B.9' had lower fruit weight than did those on other rootstocks at least in 3 of 4 years of this study (Table 3 ). Smaller fruits in trees on'B.9' were perhaps the result of a lower leaf/fruit ratio and smaller leaf size in these trees (data not shown). Fruit in trees on all rootstocks was kept at $\approx 15-\mathrm{cm}$ spacing at the time of thinning, leading to a lower leaf/ fruit ration in 'B.9' rootstock because this rootstock had a smaller canopy (Table 2) and lower foliage density (data not shown). Usually lower yield is associated with larger fruit size. However, trees on 'Sup.4' had smaller fruit despite their lower yield and thus were not considered to be suitable for planting.

Rootstock did not have a major and consistent impact on the 'Pacific Gala' fruit color. Trees on 'Sup.4' had slightly less red color than those on 'B.9' rootstock in 2 of 4 years of this study (Table 3 ) and that could be the result of the larger canopy size and thus more shading of trees on 'Sup.4' rootstock.

Fruit from trees on 'B.9' and 'G.30' often had higher SSC (Table 3) and SDP (Table 4) than those from other rootstocks. Trees on 'G.30' also had lower firmness and higher percentage of stem-end cracking than those on other rootstocks (Table 4). The trends in SSC, SDP, firmness, and stem-end cracking in the fruit from trees on 'G.30' suggest that this rootstock advances fruit maturity in 'Pacific Gala'. Based on the trends of SSC and SDP in the fruits from trees on 'B.9', this rootstock should also advance fruit maturity. However, the reason that fruit from trees on

Table 2. Effect of rootstock on tree growth, yield, and yield efficiency during different ages of tree canopy maturity in 'Pacific Gala'.,

\begin{tabular}{|c|c|c|c|c|c|c|c|c|c|c|c|c|c|c|}
\hline \multirow{2}{*}{ Rootstock } & & & & & \multicolumn{5}{|c|}{ Yield per tree $(\mathrm{kg})$} & \multicolumn{5}{|c|}{ Yield efficiency $\left(\mathrm{kg} \cdot \mathrm{cm}^{-2}\right)$} \\
\hline & \multicolumn{4}{|c|}{ TCA $\left(\mathrm{cm}^{2}\right)$} & & & & & Cumulative & & & & & Avg \\
\hline B.9 & $6.39 \mathrm{~d}$ & $8.99 \mathrm{~d}$ & $12.10 \mathrm{c}$ & $14.36 \mathrm{c}$ & $8.73 \mathrm{a}$ & $9.61 \mathrm{ab}$ & $19.39 \mathrm{~b}$ & $24.43 \mathrm{~b}$ & $64.00 \mathrm{~b}$ & $1.02 \mathrm{a}$ & $0.83 \mathrm{a}$ & $1.37 \mathrm{a}$ & $1.69 \mathrm{a}$ & $1.25 \mathrm{a}$ \\
\hline G.30 & $10.61 \mathrm{~b}$ & $18.15 \mathrm{~b}$ & $25.73 \mathrm{~b}$ & $33.17 \mathrm{~b}$ & $8.48 \mathrm{a}$ & $7.97 \mathrm{~b}$ & $13.20 \mathrm{c}$ & $42.11 \mathrm{a}$ & $75.44 \mathrm{~b}$ & $0.49 \mathrm{~b}$ & $0.33 \mathrm{c}$ & $0.45 \mathrm{c}$ & $1.29 \mathrm{~b}$ & $0.67 \mathrm{c}$ \\
\hline Sup.4 & $11.84 \mathrm{a}$ & $20.90 \mathrm{a}$ & $30.52 \mathrm{a}$ & $39.94 \mathrm{a}$ & $6.87 \mathrm{~b}$ & $2.82 \mathrm{c}$ & $6.06 \mathrm{~d}$ & $20.77 \mathrm{~b}$ & $33.85 \mathrm{c}$ & $0.34 \mathrm{c}$ & $0.10 \mathrm{~d}$ & $0.15 \mathrm{~d}$ & $0.53 \mathrm{c}$ & $0.26 \mathrm{~d}$ \\
\hline
\end{tabular}

${ }^{2}$ B.9 = 'Budagovsky 9'; RN29 = 'RN29'; G.30 = 'Cornell-Geneva30'; 'Sup.4' = 'Supporter4'; TCS = trunk cross-sectional area; Yield efficiency = yield per tree in $\mathrm{kg} / \mathrm{TCA}$ in $\mathrm{cm}^{2}$.

${ }^{y}$ Mean separation within columns by least significant difference at the $5 \%$ level. Each value represents the average of two irrigation systems; each irrigationrootstock combination has five blocks, each block with 10 trees per year, five of which are used for measurements. 
'B.9' did not have lower firmness or higher stem-end cracking than those on most other rootstocks could be the result of the existence of higher concentration of calcium in these fruits and this subject requires further study.

\section{Effects of irrigation on tree growth and yield}

Trees grown with FS irrigation had significantly $(11.3 \%)$ higher TCA (Table 5) and more new shoots (data not shown) than those with an FD system across all years of the study. Trees with FD system were more precocious and had higher yield per tree and yield efficiency than trees with FS system in 2003 (data not shown), 2004, and 2005 (Table 5). Water stress resulted in a higher production of fruiting spurs in trees with drip treatment, leading to a higher production in early years (2003-05). When trees were mature (2006 and 2007), yield and yield efficiency in both FS and FD systems were similar. Because trees with a FD system received less water (Table 1) and were more precocious with significantly higher yield per tree than those with a FS system during 2004 and 2005 (Table 5), we suggest that FD is a preferred method of irrigation over a FS system for 'Pacific Gala' apples as far as yield and water consumption factors are considered.

\section{Effect of irrigation on fruit quality attributes}

Fruit weights in 2004 and 2005 and average fruit weights over 2004-07 from trees with FD were significantly larger than those from FS treatment (Table 6). However, when trees were mature (2006 and 2007), fruit weight differences between trees with FS and FD were not significant. Larger fruit size in FD during early years after planting (2004 and 2005) was because roots in these trees were mostly concentrated where the

Table 3. Effect of rootstock on fruit weight, color, and soluble solids concentration at harvest during different ages of tree canopy maturity in 'Pacific Gala' apple. ${ }^{z, y}$

\begin{tabular}{|c|c|c|c|c|c|c|c|c|c|c|c|c|c|c|c|}
\hline \multirow[b]{3}{*}{ Rootstock } & \multicolumn{5}{|c|}{ Avg fruit wt $(g)$} & \multicolumn{5}{|c|}{ Fruit color $(1-5)^{x}$} & \multicolumn{5}{|c|}{ Soluble solids concn (\% Brix) } \\
\hline & & & & & Avg & & & & & Avg & & & & & Avg \\
\hline & 2004 & 2005 & 2006 & 2007 & $\overline{2004-07}$ & 2004 & 2005 & 2006 & 2007 & $\overline{2004-07}$ & 2004 & 2005 & 2006 & 2007 & $\overline{2004-07}$ \\
\hline B.9 & $202.3 \mathrm{c}$ & $206.9 \mathrm{~b}$ & $189.2 \mathrm{~b}$ & $157.4 \mathrm{~b}$ & $193.2 \mathrm{c}$ & $3.6 \mathrm{~b}$ & $3.1 \mathrm{a}$ & $4.1 \mathrm{a}$ & $3.3 \mathrm{a}$ & $3.5 \mathrm{ab}$ & $14.1 \mathrm{a}$ & $15.0 \mathrm{a}$ & $14.5 \mathrm{a}$ & $13.4 \mathrm{a}$ & $14.3 \mathrm{a}$ \\
\hline G.30 & $213.1 \mathrm{~b}$ & $198.3 \mathrm{~b}$ & $201.0 \mathrm{ab}$ & $184.9 \mathrm{a}$ & $200.8 \mathrm{~b}$ & $4.1 \mathrm{a}$ & $3.0 \mathrm{ab}$ & $3.8 \mathrm{ab}$ & $3.6 \mathrm{a}$ & $3.6 \mathrm{a}$ & $13.9 \mathrm{a}$ & $14.2 \mathrm{~b}$ & $14.5 \mathrm{a}$ & $13.5 \mathrm{a}$ & $14.1 \mathrm{ab}$ \\
\hline Sup.4 & $212.2 \mathrm{~b}$ & $199.8 \mathrm{~b}$ & $194.0 \mathrm{~b}$ & $190.0 \mathrm{a}$ & $200.0 \mathrm{~b}$ & $3.6 \mathrm{~b}$ & $2.7 \mathrm{~b}$ & $3.7 \mathrm{~b}$ & $3.7 \mathrm{a}$ & $3.3 \mathrm{~b}$ & $13.8 \mathrm{a}$ & $14.0 \mathrm{~b}$ & $13.8 \mathrm{~b}$ & $13.1 \mathrm{a}$ & $13.8 \mathrm{c}$ \\
\hline
\end{tabular}

${ }^{2}$ B.9 = 'Budagovsky 9'; RN29 = 'RN29'; G.30 = 'Cornell-Geneva30'; 'Sup.4' = 'Supporter4'.

${ }^{\mathrm{y}}$ Mean separation within columns by least significant difference at the $5 \%$ level. Each value represents the average of two irrigation systems; each irrigationrootstock combination has five blocks, each block with 10 trees per year, five of which are used for measurements.

${ }^{x}$ Fruit skin color rating: $1=$ least skin red color progressively to $5=$ highest skin red color.

Table 4. Effect of rootstock on fruit firmness, starch degradation pattern, and stem-end cracking at harvest during different ages of tree canopy maturity in 'Pacific Gala' apple., z,y

\begin{tabular}{|c|c|c|c|c|c|c|c|c|c|c|c|c|c|}
\hline \multirow[b]{3}{*}{ Rootstock } & \multicolumn{5}{|c|}{ Firmness $(\mathrm{N})$} & \multicolumn{5}{|c|}{ Starch degradation pattern (SDP) ${ }^{x}$} & \multicolumn{3}{|c|}{ Stem-end cracking $(\%)$} \\
\hline & & & & & Avg & & & & & Avg & & & Avg \\
\hline & 2004 & 2005 & 2006 & 2007 & $\overline{2004-07}$ & 2004 & 2005 & 2006 & 2007 & $\overline{2004-07}$ & 2006 & 2007 & 2006-07 \\
\hline B.9 & $76 \mathrm{~b}$ & $82 \mathrm{~b}$ & $86 \mathrm{a}$ & $84 \mathrm{qb}$ & $82 \mathrm{bc}$ & $4.83 \mathrm{ab}$ & $4.23 \mathrm{a}$ & $4.08 \mathrm{a}$ & $4.37 \mathrm{ab}$ & $4.39 \mathrm{a}$ & $13 \mathrm{~b}$ & $2 \mathrm{~b}$ & $8 \mathrm{~b}$ \\
\hline G.30 & $75 \mathrm{~b}$ & $85 \mathrm{~b}$ & $82 \mathrm{~b}$ & $78 \mathrm{~b}$ & $80 \mathrm{c}$ & $5.02 \mathrm{a}$ & $3.74 \mathrm{~b}$ & $3.85 \mathrm{a}$ & $4.71 \mathrm{a}$ & $4.29 \mathrm{a}$ & $45 \mathrm{a}$ & $5 \mathrm{a}$ & $25 \mathrm{a}$ \\
\hline Sup.4 & $79 \mathrm{a}$ & $89 a$ & $88 \mathrm{a}$ & $86 \mathrm{q}$ & $86 \mathrm{a}$ & $4.62 \mathrm{~b}$ & $3.40 \mathrm{c}$ & $3.18 \mathrm{~b}$ & $3.96 \mathrm{~b}$ & $3.77 \mathrm{~b}$ & $20 \mathrm{~b}$ & $6 \mathrm{a}$ & $11 \mathrm{~b}$ \\
\hline
\end{tabular}

'B.9 = 'Budagovsky 9'; RN29 = 'RN29'; G.30 = 'Cornel-Geneva30'; 'Sup.4' = 'Supporter4'.

${ }^{\mathrm{y}}$ Mean separation within columns by least significant difference at the $5 \%$ level. Each value represents the average of two irrigation systems; each irrigationrootstock combination has five blocks, each block with 10 trees per year, five of which are used for measurements.

${ }^{\mathrm{x}} \mathrm{SDP}=$ fruit starch degradation pattern $=$ least mature $=1$ progressively to completely mature $=6$.

Table 5. Effect of irrigation system on tree growth, yield per tree, and yield efficiency during different ages of tree canopy maturity in 'Pacific Gala' apple.,y

\begin{tabular}{|c|c|c|c|c|c|c|c|c|c|c|c|c|c|c|}
\hline \multirow[b]{3}{*}{ Irrigation } & & & & & \multicolumn{5}{|c|}{ Yield per tree $(\mathrm{kg})$} & \multicolumn{5}{|c|}{ Yield efficiency $\left(\mathrm{kg} \cdot \mathrm{cm}^{-2}\right)$} \\
\hline & \multicolumn{4}{|c|}{ TCA $\left(\mathrm{cm}^{2}\right)$} & & & & & Cumulative & & & & & Avg \\
\hline & 2003 & 2004 & 2005 & 2006 & 2004 & 2005 & 2006 & 2007 & $\overline{2004-07}$ & 2004 & 2005 & 2006 & 2007 & $\overline{2004-07}$ \\
\hline Sprinkler & $10.03 \mathrm{a}$ & $17.18 \mathrm{a}$ & $24.32 \mathrm{a}$ & $31.27 \mathrm{a}$ & $7.70 \mathrm{~b}$ & $6.23 \mathrm{~b}$ & $15.44 \mathrm{a}$ & $35.26 \mathrm{a}$ & $64.25 \mathrm{a}$ & $0.52 \mathrm{~b}$ & $0.34 \mathrm{~b}$ & $0.63 \mathrm{a}$ & $1.32 \mathrm{a}$ & $0.72 \mathrm{a}$ \\
\hline Drip & $9.16 \mathrm{~b}$ & $15.14 \mathrm{~b}$ & $21.71 \mathrm{~b}$ & $27.73 \mathrm{~b}$ & $9.04 \mathrm{a}$ & $9.82 \mathrm{a}$ & $16.42 \mathrm{a}$ & $30.30 \mathrm{a}$ & $66.16 \mathrm{a}$ & $0.69 \mathrm{a}$ & $0.55 \mathrm{a}$ & $0.73 \mathrm{a}$ & $1.14 \mathrm{a}$ & $0.77 \mathrm{a}$ \\
\hline
\end{tabular}

${ }^{\mathrm{z}} \mathrm{TCA}=$ trunk cross-sectional area; Yield efficiency $=$ yield per tree in $\mathrm{kg} / \mathrm{TCA}$ in $\mathrm{cm}^{2}$.

${ }^{y}$ Mean separation within columns by least significant difference at the 5\% level. Each value represents the average of four rootstocks. Each irrigation-rootstock combination has five blocks, each block with 10 trees per year, five of which are used for measurements.

Table 6. Effect of irrigation system on fruit weight, color, and soluble solids concentration at harvest during different ages of tree canopy maturity in 'Pacific Gala' apple.

\begin{tabular}{|c|c|c|c|c|c|c|c|c|c|c|c|c|c|c|c|}
\hline \multirow[b]{3}{*}{ Irrigation } & \multicolumn{5}{|c|}{ Avg fruit wt (g) } & \multicolumn{5}{|c|}{ Color $^{\mathrm{y}}$} & \multicolumn{5}{|c|}{ Soluble solids concn ( $\%$ Brix $)$} \\
\hline & & & & & Avg & & & & & Avg & & & & & Avg \\
\hline & 2004 & 2005 & 2006 & 2007 & $\overline{2004-07}$ & 2004 & 2005 & 2006 & 2007 & $\overline{2004-07}$ & 2004 & 2005 & 2006 & 2007 & $\overline{2004-07}$ \\
\hline Sprinkler & $206.8 \mathrm{~b}$ & $198.9 \mathrm{~b}$ & $199.0 \mathrm{a}$ & $182.7 \mathrm{a}$ & $198.5 \mathrm{~b}$ & $3.9 \mathrm{a}$ & $3.1 \mathrm{a}$ & $4.0 \mathrm{a}$ & $3.8 \mathrm{a}$ & $3.69 \mathrm{a}$ & $13.9 \mathrm{~b}$ & $14.5 \mathrm{a}$ & $14.0 \mathrm{a}$ & $13.5 \mathrm{a}$ & $14.0 \mathrm{a}$ \\
\hline Drip & $219.1 \mathrm{a}$ & $214.8 \mathrm{a}$ & $198.2 \mathrm{a}$ & $177.3 \mathrm{a}$ & $205.7 \mathrm{a}$ & $3.5 \mathrm{~b}$ & $2.7 \mathrm{~b}$ & $3.7 \mathrm{~b}$ & $3.3 \mathrm{~b}$ & $3.27 \mathrm{~b}$ & $14.1 \mathrm{a}$ & $14.0 \mathrm{~b}$ & $14.4 \mathrm{a}$ & $13.2 \mathrm{a}$ & $14.0 \mathrm{a}$ \\
\hline
\end{tabular}

${ }^{\mathrm{z}}$ Mean separation within columns by least significant difference at the 5\% level. Each value represents the average of four rootstocks; each irrigation-rootstock combination has five blocks, each block with 10 trees per year, five of which are used for measurements. Fruit skin color rating: 1 = least skin red color progressively to $5=$ highest red color. 
Table 7. Effect of irrigation system on fruit firmness, starch degradation pattern, and stem-end cracking at harvest during different ages of tree canopy maturity in 'Pacific Gala' apple.,

\begin{tabular}{|c|c|c|c|c|c|c|c|c|c|c|c|c|c|}
\hline \multirow{2}{*}{ Irrigation } & \multicolumn{5}{|c|}{ Firmness $(\mathrm{N})$} & \multicolumn{5}{|c|}{ Starch (SDP) } & \multicolumn{3}{|c|}{ Stem-end cracking (\%) } \\
\hline & & & & & Avg & & & & & Avg & & & Avg \\
\hline Sprinkler & $79 \mathrm{a}$ & $88 \mathrm{a}$ & $86 \mathrm{a}$ & $81 \mathrm{a}$ & $84 \mathrm{a}$ & $4.69 \mathrm{a}$ & $3.60 \mathrm{~b}$ & $3.49 \mathrm{a}$ & $4.37 \mathrm{a}$ & $3.99 \mathrm{~b}$ & $21 \mathrm{a}$ & $6 \mathrm{a}$ & $14 \mathrm{a}$ \\
\hline
\end{tabular}

${ }^{\mathrm{z}}$ Mean separation within columns by least significant difference at the $5 \%$ level. Each value represents the average of four rootstocks; each irrigation-rootstock combination had five blocks, each block with 10 trees per year, five of which are used for measurements.

${ }^{\mathrm{y}} \mathrm{SDP}=$ fruit $\mathrm{starch}$ degradation pattern $=$ least mature $=1$ progressively to completely mature $=6$.

irrigation was applied and thus causing larger fruits. In 2006 and 2007, roots of trees receiving an FS irrigation system were expanded and were able to uptake more of the water that was applied to a distance from the tree.

'Pacific Gala' fruit from trees with FS consistently had better color than those with an FD system every year (Table 6) that could be the result of the cooler temperatures that prevailed under trees with an FS system (data not shown). Also 'Pacific Gala' leaves from trees with FS irrigation always had significantly lower magnesium $(\mathrm{Mg})$ than those on FD every year (data not shown). Because $\mathrm{Mg}$ is the central part of the chlorophyll structure, trees on a FS system could have had lower chlorophyll concentration, leading to higher red color, and this subject merits further study.

There was no consistent effect of irrigation system on fruit SSC (Table 6). However, fruit from trees with the FD system often had lower firmness and higher SDP than those from FS irrigation, suggesting that fruit with FD were slightly more mature as a result of water stress as compared with trees with an FS system. Nevertheless, this advanced maturity did not cause a major difference in fruit stem-end cracking between the two irrigation treatments (Table 7). Factors that lead to a greater hydrolysis of fruit starch can result in higher SSC in apples (Kramer, 1983). Despite being a useful test, a simple fruit dip in iodine solution (SDP) may not always be a reliable measure of the starch concentration of fruit. For example, in our study in 2005, fruit from trees receiving FD treatment had a significantly lower SSC than those from FS irrigation regime (Table 6), whereas fruits in FD had a higher level of SDP than those in FS treatment (Table 7). This could be the result of conversion of simple sugar to other metabolites.

Ebel et al. (1993) reported that 'Delicious' apple fruit from trees receiving early-season RDI treatment were smaller and had a higher SSC and lower SDP that those from wellwatered trees. However, they did not observe any difference in the color or firmness of fruits from RDI and well-watered trees. Leib et al. (2006) showed that SSC in fruit from trees receiving DI was higher than in fruit from trees receiving CI. A 2-year study by O'Connell and Goodwin (2007) on 'Pink Lady' in Victoria, Australia, showed that SSC tended to be higher in DI fruit than CI fruit for each of the 2 years. In contrast,
Talluto et al. (2008) reported that 'Pink Lady' fruits from DI and CI treatments had similar SSC. Differences in the volume of water applied in deficit irrigation treatments and method of calculation for water requirement (ETc vs. soil moisture content) could partially explain these contradictory reports.

\section{Conclusions and General Comment}

A significantly greater volume of water is required for trees under full microjet sprinkler systems than those with drip systems. Application of water through a drip system, based on full ETc rate and adjusted by percentage of GS, can result in major water savings and often improves yield and fruit quality. Considering yield and fruit attributes, 'B.9' and 'RN29' appear to be excellent rootstocks for 'Pacific Gala', whereas 'Sup.4' is not desirable under conditions of this study. 'B.9' and 'G.30' rootstocks advance maturity of 'Pacific Gala' apple.

With an increasing demand for new cultivars, higher orchard tree density, and different canopy architectures, the impact of various irrigation systems and newer rootstocks on fruit quality and yield of apples needs to be further studied.

\section{Literature Cited}

Allen, R.G., L.S. Pereira, D. Raes, and M. Smith. 1998. Crop evapotranspiration. Guidelines for computing crop water requirements. FAO Irr. Drainage Paper 56. FAO, Rome, Italy.

Assaf, R., I. Levin, and B. Bravdo. 1975. Effect of irrigation regimes on trunk and fruit growth rates, quality and yield. J. Hort. Sci. 50:481493.

Autio, W.R., R.A. Hayden, W.C. Micke, and G.R. Brown. 1996. Rootstock affects ripening, color, and shape of 'Starkspur Supreme Delicious' apples in the 1984 NC-140 cooperative planting. Fruit Var. J. 50:45-53.

Bartram, R.D., W. Bramlage, E.M. Kupferman, K.L. Olsen, M.E. Patterson, and J. Thompson. 1993. Apple maturity program handbook. U.S. Dept. Agri. Res. Serv. Tree Fruit Research Station, Wenatchee, WA.

Behboudian, M.H. and T.M. Mills. 1997. Deficit irrigation in deciduous orchards. Hort. Rev. 21:105-131.

Behboudian, M.H., B.S. Mpelasoka, Z. Singh, and T.M. Mills. 2005. Quality responses of deciduous fruit to deficit irrigation, p. 33-43. In: Dris, R. (ed.). Fruit: Growth, nutrition, and quality. WFL Publisher (Science \& Technology), Helsinki, Finland.

Chun, I.J., E. Fallahi, W.M. Colt, B. Shafii, and R.R. Tripepi. 2001. Effects of rootstocks and microsprinkler fertigation on mineral concentrations, yield, and fruit color of 'BC-2 Fuji' apple. J. Amer. Pomol. Soc. 55:197-205.

Drake, S.R., E.L. Proebsting, M.O. Mahan, and J.B. Thompson. 1981. Influence of trickle and sprinkle irrigation on 'Golden Delicious' apple quality. J. Amer. Soc. Hort. Sci. 106:255258.

Ebel, R.C., E.L. Proebsting, and M.E. Patterson. 1993. Regulated deficit irrigation may alter apple maturity, quality, and storage life. HortScience 28:141-143.

Fallahi, E., W.M. Colt, and B. Fallahi. 2001a. Optimum ranges of leaf nitrogen for yield, fruit quality, and photosynthesis in 'BC-2 Fuji'. Apple. J. Amer. Pomol. Soc. 55:68-75.

Fallahi, E., I.J. Chun, G.H. Neilsen, and W.M. Colt. $2001 \mathrm{~b}$. Effects of three rootstocks on photosynthesis, leaf mineral nutrition, and vegetative growth of 'BC-2 Fuji' apple trees. J. Plant Nutr. $24: 827-834$

Fallahi, E., B. Fallahi, B. Shafii, and B. Morales. 2007a. Water use, tree growth, and leaf mineral nutrients of young 'Fuji' apples as influenced by different irrigation systems. Acta Hort. 721:63-70.

Fallahi, E., R. Ratnaprabha, R. Tripepi, B. Shafii, and B. Fallahi. 2007b. Tree growth, yield, fruit quality, and mineral partitioning as affected by rootstock and irrigation methods. Intl. J. Fruit Sci. 7:3-24.

Kramer, P.J. 1983. Water relations of plants. Academic Press, New York, NY.

Leib, B.G., H.W. Caspari, C.A. Redulla, P.K. Andrews, and J.J. Jabro. 2006. Partial root zone drying and deficit irrigation of 'Fuji' apples in a semi-arid climate. Irr. Sci. 85-99.

Mills, T.M., M.H. Behboudian, P.Y. Tan, and B.E Clothier. 1994. Plant water status and fruit quality in 'Braeburn' apples. HortScience 29: 1274-1278.

Naor, A., S. Naschitz, M. Peres, and Y. Gal. 2008. Responses of apple fruit size to tree water status and crop load. Tree Physiol. 28:1255-1261.

Neilsen, D., G.H. Neilsen, D. Gregory, T. Forge, and B.J. Zebarth. 2008. Drainage losses of water, $\mathrm{N}$ and $\mathrm{P}$ from micro-irrigation systems in a young, high density apple planting. Acta Hort. 792:483-490.

Neilsen, D., G.H. Neilsen, L. Herbert, and S. Guak. 2010. Effect of irrigation and crop load management on fruit nutrition and quality for Ambrosia/M.9 apple. Acta Hort. 868:63-72.

Neilsen, D., S. Smith, G. Frank, W. Koch, Y. Alila, W. Merritt, B. Taylor, M. Barton, J. Hall, and S. Cohen. 2006. Potential impacts of climate change on water availability for crops in the Okanagan Basin, British Columbia. Can. J. Soil Sci. 86:909-924.

Neilsen, G.H., P. Parchomchuck, and D. Neilsen. 1994. Fertigation of fruit trees: The B.C. experience, p. 191-199. In: Peterson, A.B. and R.G. Stevens (eds.). Tree fruit nutrition. Good Fruit Grower, Yakima, WA. 
O’Connell, M.G. and I. Goodwin. 2007. Responses of 'Pink Lady' apple to deficit irrigation and partial root zone drying: Physiology, growth, yield, and fruit quality. Austral. J. Agr. Res. 58:1068-1076.

Proebsting, E. 1994. Strategy development for managing drought, p. 39-50. In: Williams, K.M. and T.W. Ley (eds.). Tree fruit irrigation. Good Fruit Grower, Yakima, WA.
Talluto, G., V. Farina, G. Volpe, and R. Lo Bianco. 2008. Effects of partial root zone drying and rootstock vigor on growth and fruit quality of 'Pink Lady' apple trees in Mediterranean environments. Austral. J. Agr. Res. 59:785-794.

Washington State University. 2012. Washington State University Tree Fruit Research and Extension Center. 20 Mar. 2012. <http://www. tfrec.wsu.edu>.
Yao, S., G.H. Neilsen, and D. Neilsen. 2001. Effects of water stress on growth and mineral composition of 'Gala' apple fruit. Acta Hort. 564:449-456.

Zydlik, Z. and E. Pacholak. 2001. Fertigation effects on the concentration of mineral components in the soil and leaves, and the yield and quality of fruit in two apple tree cultivars. Acta Hort. 564:457-463. 